\title{
Suspicion and treatment of severe sepsis. An overview of the prehospital chain of care
}

\author{
Johan Herlitz ${ }^{1,3 *}$, Angela Bång ${ }^{1}$, Birgitta Wireklint-Sundström ${ }^{1}$, Christer Axelsson ${ }^{1}$, Anders Bremer ${ }^{1}$, \\ Magnus Hagiwara', Anders Jonsson ${ }^{1}$, Lars Lundberg ${ }^{1}$, Björn-Ove Suserud ${ }^{1}$ and Lars Ljungström²
}

\begin{abstract}
Background: Sepsis is a life-threatening condition where the risk of death has been reported to be even higher than that associated with the major complications of atherosclerosis, i.e. myocardial infarction and stroke. In all three conditions, early treatment could limit organ dysfunction and thereby improve the prognosis.

Aim: To describe what has been published in the literature a/ with regard to the association between delay until start of treatment and outcome in sepsis with the emphasis on the pre-hospital phase and b/ to present published data and the opportunity to improve various links in the pre-hospital chain of care in sepsis.

Methods: A literature search was performed on the PubMed, Embase (Ovid SP) and Cochrane Library databases. Results: In overall terms, we found a small number of articles ( $n=12$ of 1,162 unique hits) which addressed the prehospital phase. For each hour of delay until the start of antibiotics, the prognosis appeared to become worse. However, there was no evidence that prehospital treatment improved the prognosis.

Studies indicated that about half of the patients with severe sepsis used the emergency medical service (EMS) for transport to hospital. Patients who used the EMS experienced a shorter delay to treatment with antibiotics and the start of early goal-directed therapy (EGDT). Among EMS-transported patients, those in whom the EMS staff already suspected sepsis at the scene had a shorter delay to treatment with antibiotics and the start of EGDT.

There are insufficient data on other links in the prehospital chain of care, i.e. patients, bystanders and dispatchers.

Conclusion: Severe sepsis is a life-threatening condition. Previous studies suggest that, with every hour of delay until the start of antibiotics, the prognosis deteriorates. About half of the patients use the EMS. We need to know more about the present situation with regard to the different links in the prehospital chain of care in sepsis.
\end{abstract}

Keywords: Sepsis, Dispatch centre, Emergency medical service

\section{Background}

There are a number of conditions in medicine, where every minute counts and the time from the onset of symptoms until the delivery of life-saving treatment is of ultimate importance. During the last few decades, this has resulted in improvements in the early chain of care in outof-hospital cardiac arrest, presumed acute coronary syndrome (ACS) and stroke. This has resulted in a major

\footnotetext{
* Correspondence: johan.herlitz@gu.se

${ }^{1}$ School of Health Sciences, Research Centre PreHospen, University of Borås, The Prehospital Research Centre of Western Sweden, SE 501 90, Borås, Sweden

${ }^{3}$ Sahlgrenska University Hospital, SE 413 45, Göteborg, Sweden

Full list of author information is available at the end of the article
}

improvement in prognosis, particularly with regard to ACS but also in out-of-hospital cardiac arrest [1].

Severe sepsis is now considered to be the most common cause of death in non-coronary intensive care units. Approximately 150,000 people die every year in Europe and $>200,000$ die annually in the United States [2].

It appears that the delay from symptom onset until the delivery of treatment is important for outcome [3-7].

However, aspects of the very early chain of care, i.e. the prehospital chain of care, have not been evaluated extensively. With improvement in the very early chain of care in sepsis treatment could hopefully start even earlier.

As with cardiac arrest, ACS and stroke, the prehospital chain of care can be divided into four links or perspectives: 1/ the patients' perspective; $2 /$ the bystanders'

\section{Biomed Central}


Table 1

\begin{tabular}{|c|c|c|}
\hline Questions & Answers & References \\
\hline \multicolumn{3}{|l|}{ General } \\
\hline $\begin{array}{l}\text { - Is there an association between delay from } \\
\text { symptom onset until start of treatment and outcome? }\end{array}$ & $\begin{array}{l}\text { Yes, however data with regard to the value } \\
\text { of pre hospital treatment with antibiotics } \\
\text { are controversial }\end{array}$ & $3,4,5,6,7,23,24,25,27,28,29,30$ \\
\hline \multicolumn{3}{|l|}{ patient's perspective } \\
\hline What is the patient decision time? & $\mathrm{n} / \mathrm{a}$ & \\
\hline $\begin{array}{l}\text { - Can we define factors associated with } \\
\text { prehospital delay? }\end{array}$ & $\mathrm{n} / \mathrm{a}$ & \\
\hline $\begin{array}{l}\text { Why do patients with sepsis wait before } \\
\text { deciding to go to hospital? }\end{array}$ & $\mathrm{n} / \mathrm{a}$ & \\
\hline \multicolumn{3}{|l|}{ bystander's perspective } \\
\hline . What are their thoughts and feelings? & $\mathrm{n} / \mathrm{a}$ & \\
\hline - Which action do they take and why? & $\mathrm{n} / \mathrm{a}$ & \\
\hline - Can we identify bystanders of high-risk patients? & $\mathrm{n} / \mathrm{a}$ & \\
\hline \multicolumn{3}{|l|}{ dispatcher's perspective } \\
\hline $\begin{array}{l}\text { What signs and symptoms appear to the dispatchers } \\
\text { by telephone in sepsis? }\end{array}$ & $\mathrm{n} / \mathrm{a}$ & \\
\hline How often do the dispatchers suspect sepsis? & $\mathrm{n} / \mathrm{a}$ & \\
\hline $\begin{array}{l}\text { - Can a decision support system improve the } \\
\text { accuracy of their prioritization? }\end{array}$ & $\mathrm{n} / \mathrm{a}$ & \\
\hline \multicolumn{3}{|l|}{ The EMS perspective } \\
\hline . How often do patients with sepsis use the EMS? & $\ln 50-60 \%$ & $32,33,34$ \\
\hline . How often do the EMS staffs suspect sepsis? & $\ln 20-50 \%$ & 32,36 \\
\hline \multirow{2}{*}{$\begin{array}{l}\text { - Is it possible to improve the EMS staffs' } \\
\text { accuracy in detecting sepsis? }\end{array}$} & (1) Limited knowledge among EMS staff & 38 \\
\hline & $\begin{array}{l}\text { (2) Biochemical markers might } \\
\text { improve outcome }\end{array}$ & 39 \\
\hline
\end{tabular}

$\mathrm{n} / \mathrm{a}=$ not available.

perspective; $3 /$ the dispatchers' perspective and $4 /$ the emergency medical service's (EMS) perspective.

Our hypothesis is that in each of these four links there is room for improvement and that improvement might result in a shortening in delay to treatment in sepsis.

In each of these four links, a number of questions arise which focus on patterns of reaction, reasons for delay, the association between delay and outcome and opportunities for improvement.

Table 1 shows the most relevant questions that were addressed in the survey with regard to these four links.

\section{Definition of sepsis [8]}

\section{Sepsis}

The diagnostic criteria can be divided into five domains.

\section{General criteria}

These include a/ fever (core temperature $>38.3 \mathrm{C}$ ) or hypothermia (i.e. core temperature $<36 \mathrm{C}$ ); b/ heart rate $>90$ beats $/ \mathrm{min}$ or $>2 \mathrm{SD}$ above the normal value for age; c/ tachypnea; $d$ / altered mental status; e/ significant oedema or positive fluid balance and f/ hyperglycaemia (plasma glucose $>7.7 \mathrm{mmol} / \mathrm{l}$ in the absence of diabetes).

\section{Inflammatory variables}

a/ leukocytosis; b/ leukopenia; c/ normal leucocyte count but $>10 \%$ immature forms; $d /$ plasma C-reactive protein $>$ 2SD above normal limit; e/ plasma procalcitonin $>2$ SD above normal limit.

\section{Haemodynamic variables}

a/ arterial hypotension (systolic blood pressure $<90 \mathrm{mmHg}$ ); $\mathrm{b} / \mathrm{SVO}_{2}>70 \%$; $/$ cardiac index $>3.5 \mathrm{~L} / \mathrm{min}$

\section{Organ dysfunction variables}

a/ arterial hypoxemia; b/ acute oliguria; c/ creatinine increase; d/ coagulation abnormality; e/ ileus; f/ thrombocytopenia; g/ hyperbilirubinemia 


\section{Tissue perfusion variables}

a/ hyperlactatemia; b/ reduced capillary filling.

It is important to stress that few if any patients in the early stages of the inflammatory responses to infection are diagnosed via four arbitrary criteria.

Instead, the health care provider, at bedside, identifies "myriad symptoms" and, regardless of evident infection, declares the patient to "look septic".

\section{Severe sepsis}

The definition of severe sepsis relates to sepsis complicated by organ dysfunction. Organ dysfunction can be defined using the definition formulated by Marshall et al. [9] or the definition used for the Sequential Organ Failure Assessment (SOFA) score [10] as suggested by ref [8] and [11].

\section{Septic shock}

This relates to the state of acute circulatory failure characterised by persistent arterial hypotension unexplained by other causes. Hypotension is defined as systolic blood pressure of $<90 \mathrm{~mm} \mathrm{Hg}$ (or in children $<2 \mathrm{SD}$ below the norm for their age).

\section{Definition of delay}

The delay which is mostly referred to in the acute phase of a life-threatening condition is the delay from the onset of symptoms until the start of treatment. When it comes to the treatment of sepsis, there are three major aspects of treatment, i.e. antibiotics, fluids and respiratory support. To date, these treatments have generally been started after admission to hospital [12-20].

One problem that might appear in sepsis is the definition of symptom onset. In all probability, many patients will have problems giving an exact time for the onset of symptoms, whereas others can describe the time of the symptom onset more exactly. This is a problem that is not unique to sepsis. Similar problems have been raised both in acute myocardial infarction [21] and in stroke [22].

When including the prehospital phase in the acute chain of care, the delay from symptom onset until the delivery of treatment can be divided into patient delay, i.e. the delay from the onset of symptoms until the patient calls for an ambulance or contacts other healthcare providers, and system delay, i.e. the delay between the first contact with health-care providers and the start of treatment.

Table 2 EMBASE 2011-07-06

\begin{tabular}{|c|c|c|}
\hline \multicolumn{3}{|c|}{ Database(s): EMBASE 1980 to present } \\
\hline \multicolumn{3}{|c|}{ Search strategy: } \\
\hline$\#$ & Searches & Results \\
\hline 1 & exp septicaemia/or septicaemia.mp. & 18,156 \\
\hline 2 & sepsis.mp. or exp sepsis/ & 143,927 \\
\hline 3 & patient delays.mp. & 63 \\
\hline 4 & exp bystander effect/or bystander.mp & 5,711 \\
\hline 5 & exp witness/or witnessed.mp. & 8,488 \\
\hline 6 & dispatch.mp & 914 \\
\hline 7 & patient delays.af. & 63 \\
\hline 8 & patient delay.af. & 448 \\
\hline 9 & (witness or witnesses or witnessed).af & 21,125 \\
\hline 10 & bystander.af. & 5,711 \\
\hline 11 & dispatch.af. & 928 \\
\hline 12 & (septicaemia or sepsis).af. & 112,005 \\
\hline 13 & Emergency Medical Services.mp.or exp emergency health service/ & 51,496 \\
\hline 14 & Emergency Medical Services.af. & 6,827 \\
\hline 16 & ambulances.mp. or exp ambulance/ & 6,776 \\
\hline 16 & (ambulance or ambulances).af. & 10,308 \\
\hline 17 & 1 or 2 or 12 & 147,364 \\
\hline 18 & 3 or 4 or 5 or 6 or 7 or 8 or 9 or 10 or 11 or 13 or 14 or 15 or 16 & 85,897 \\
\hline 19 & 17 and 18 & 609 \\
\hline 20 & limit 19 to Embase and (Danish or English or Norwegian or Swedish) & 402 \\
\hline
\end{tabular}



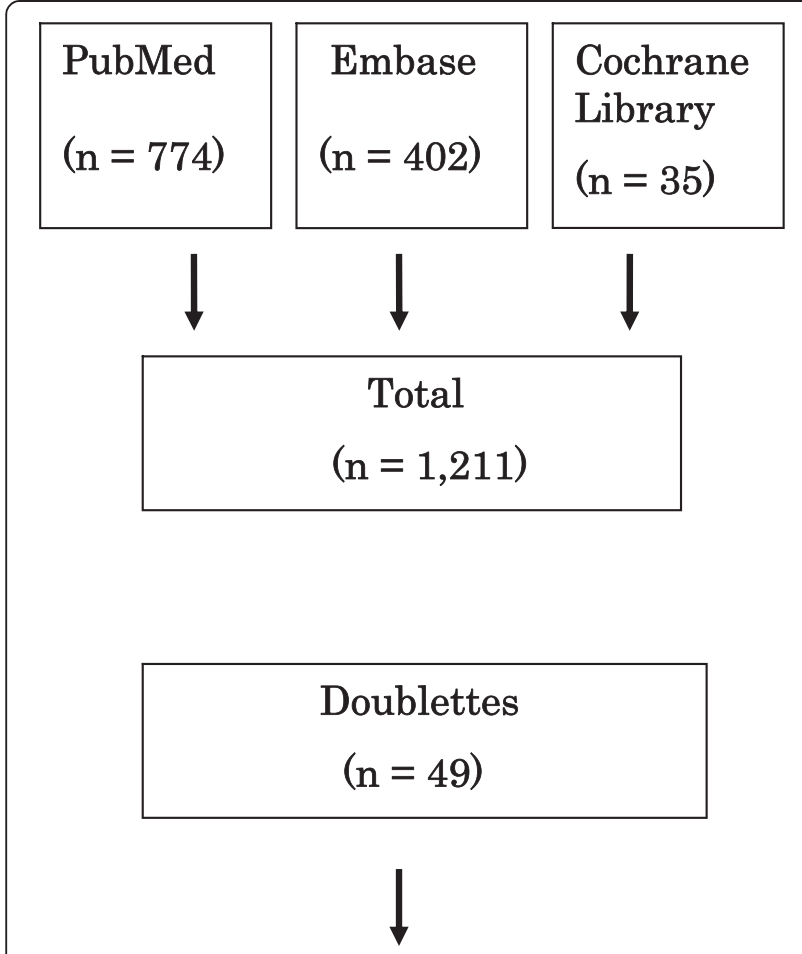

Number of unique hits

$$
(\mathrm{n}=1,162)
$$

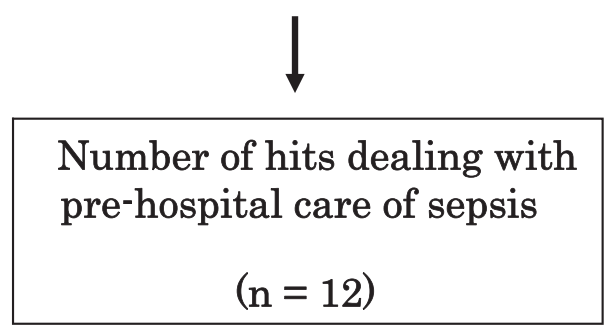

Figure 1 Number of hits in the various databases.

The aim of this survey was to describe what has been published in the literature with regard to a/ the association between delay until start of treatment and outcome in sepsis with the emphasis on the prehospital phase and $\mathrm{b} /$ present knowledge and the opportunity to improve various links in the prehospital chain of care in sepsis. The ultimate goal is to find new ways to shorten delay to treatment in sepsis and thereby improve survival.

\section{Methods}

In June 2011, literature searches were performed in the PubMed, EMBASE (Ovid SP) and Cochrane Library databases. Variations of the following terms were used, adapted for each database:

septicaemia, sepsis, patient delays, bystander effect, witness, dispatch, Emergency Medical Services, emergency health service, ambulances.

An example of the number of hits is shown below for Embase (Table 2).

The number of hits fulfilling the criteria given is shown in Figure 1.

Table 3 shows the 12 articles which dealt with the prehospital setting and their major aims and conclusions.

\section{Results}

\section{Association between delay to delivery of treatment and outcome (Table 1)}

Some studies have reported an association between delay to the delivery of antibiotics and outcome in severe infection [6,7].

However, several studies have reported that children who received parenteral penicillin from general practitioners (GP) prior to arrival in hospital had a more severe outcome than those that did not [23-25].

One further study showed that paramedic compliance with guidelines when administering benzyl penicillin in presumed meningococcal disease in the prehospital setting was relatively low [26].

It was suggested that patients who received penicillin prior to arrival in hospital were more severely ill [23]. In the majority of these cases, the patients were suffering from meningococcal sepsis, which has been reported to have an extremely poor prognosis.

However, others have reported that the prehospital administration of antibiotics is associated with a more favourable outcome [27-30].

During the last few decades, "Early goal-directed therapy" (EGDT) in sepsis has been introduced at emergency departments (ED) in many countries. This treatment algorithm has been used in particular among patients with septic shock unresponsive to fluid challenges [3].

\section{The four links in the chain of care in the prehospital setting \\ The patient}

Decision time and overall prehospital delay The delay from the onset of symptoms to the decision to go to hospital or the decision to call for the EMS is insufficiently reported in the literature. Similarly, the overall prehospital delay from the onset of symptoms to arrival in hospital and factors associated with this delay are not known.

\section{The bystander}

In other conditions such as ACS and stroke, the bystander (often a wife or husband) is looked upon as a 
Table 3 Prehospital studies of sepsis

\begin{tabular}{|c|c|c|c|c|}
\hline Ref & Year & Aim & $\mathrm{n}$ & Results \\
\hline \multicolumn{5}{|c|}{ A. Prehospital treatment } \\
\hline \multicolumn{5}{|c|}{ (1) Meningococcal sepsis } \\
\hline 23 & 1998 & To assess the effect of antibiotics given by GP & 32 & $\begin{array}{l}\text { Higher mortality among patients who } \\
\text { received antibiotics }\end{array}$ \\
\hline 24 & 2002 & To assess the effect of antibiotics given by GP & 534 & $\begin{array}{l}\text { The effect of prehospital antibiotics appeared to } \\
\text { be dependent on hospital care }\end{array}$ \\
\hline 25 & 2006 & $\begin{array}{l}\text { To explore mortality and morbidity after parenteral } \\
\text { penicillin in children }\end{array}$ & 158 & $\begin{array}{l}\text { Children who were given antibiotics had a } \\
\text { more severe disease on admission to hospital }\end{array}$ \\
\hline 26 & 2005 & $\begin{array}{l}\text { Audit to determine the clinical appropriateness of } \\
\text { administrations of benzyl penicillin by paramedics }\end{array}$ & 69 & $\begin{array}{l}\text { Paramedic compliance with guidelines } \\
\text { was low (78\% failures) }\end{array}$ \\
\hline \multicolumn{5}{|c|}{ (2) Fluids } \\
\hline 36 & 2010 & $\begin{array}{l}\text { To determine the delivery of out-of -hospital fluids } \\
\text { in severe sepsis }\end{array}$ & 52 & Forty-eight per cent received intravenous fluids \\
\hline \multicolumn{5}{|c|}{ B. Impact of EMS on care of sepsis patients } \\
\hline 32 & 2010 & $\begin{array}{l}\text { To evaluate early recognition and treatment in } \\
\text { relation to EMS care }\end{array}$ & 311 & $\begin{array}{l}\text { Patients who used the EMS had more organ } \\
\text { failure but a shorter time to antibiotics and EGDT }\end{array}$ \\
\hline 33 & 2010 & $\begin{array}{l}\text { To characterise patients with sepsis in relation to the } \\
\text { use of the EMS }\end{array}$ & 4,613 & $\begin{array}{l}\text { EMS patients were more likely to present } \\
\text { with severe sepsis }\end{array}$ \\
\hline 34 & 2010 & $\begin{array}{l}\text { To describe out-of-hospital characteristics and EMS care } \\
\text { among patients with severe sepsis who used the EMS }\end{array}$ & 216 & $\begin{array}{l}\text { Out-of-hospital variables were associated } \\
\text { with organ dysfunction at the ED }\end{array}$ \\
\hline 42 & 2011 & $\begin{array}{l}\text { To assess the impact of the EMS on time to antibiotics, } \\
\text { intravenous fluids and mortality in severe sepsis }\end{array}$ & 963 & $\begin{array}{l}\text { Out-of-hospital care was associated with improved } \\
\text { in-hospital processes but not mortality }\end{array}$ \\
\hline
\end{tabular}

\section{Prediction of outcome}

$392009 \quad$ To consider how prehospital staff can improve the outcome in severe sepsis

$352007 \quad$ To assess the predictive effect of physiological elements commonly reported in the out-of-hospital setting on the

D. Knowledge and attitudes regarding sepsis among EMS staff

63 The out-of-hospital shock index and respiratory

The article suggests that antibiotics should be given in the prehospital setting and that lactate should be measured

\begin{tabular}{|c|c|c|c|c|}
\hline 38 & 2010 & $\begin{array}{l}\text { To assess the knowledge and attitudes in the } \\
\text { diagnosis and management of sepsis in the USA }\end{array}$ & 226 & $\begin{array}{l}\text { Poor understanding of the principles of diagnosis } \\
\text { and management of sepsis was observed }\end{array}$ \\
\hline
\end{tabular}

$\mathrm{GP}=$ General practitioner.

EMS = Emergency Medical Services.

EGDT $=$ Early Goal Directed Therapy.

$\mathrm{ED}=$ Emergency Department.

key link, since the patient is often suffering from denial and, in stroke in particular, is unable to think clearly [31]. Whether this is true also for sepsis is not well described in the literature.

\section{The dispatch centre}

Among patients with sepsis where the EMS has been called upon, the dispatch centre and the dispatchers play a key role.

The prioritisation and the dispatcher's possible suspicion of a life-threatening condition might be of ultimate importance for the patient's outcome. There is, unfortunately, no information in the literature with regard to these issues.

\section{The EMS}

How often do patients with sepsis use the EMS? In one prospective observational study including ED patients with severe sepsis treated with EGDT, $51 \%$ were transported by the EMS [32]. Others report that the EMS provided care for about $60 \%$ of patients with severe sepsis $[33,34]$.

How often do the EMS staff suspect sepsis and, if so, are they able to predict outcome? In one report, the EMS staff had a primary impression of sepsis in $21 \%$ of EMS-transported sepsis patients [32].

In another report, it was shown that the out-ofhospital shock index and respiratory rate were highly 
predictive of intensive care unit admission [35]. In another study, only half of 52 patients with severe sepsis received out-of-hospital fluid [36].

Which criteria do they use? In the prehospital setting, the health-care providers can obtain valuable information from general variables (hyper- or hypothermia, elevated heart rate and tachypnea).

They can also obtain valuable information from hemodynamic variables (hypotension), as well as signs of organ dysfunction (arterial hypoxemia).

As a result, the combination of elevated heart rate, an oxygen saturation of $<90 \%$ and a respiratory rate of $>30$ per minutes, in combination with hyper- or hypothermia, should raise a strong suspicion of severe sepsis [37]. If this is combined with systolic blood pressure of below $90 \mathrm{mmHg}$, there is a strong suspicion of septic shock [37].

Do the EMS staff follow these criteria? This is not well reported in the literature. A recent report suggests limited knowledge among EMS staff regarding various aspects of sepsis [38].

Is it possible to improve the EMS staff's accuracy in detecting sepsis? It is not unlikely that education and feedback to the EMS staff might improve their alertness to detect sepsis already in the prehospital setting. It has been suggested that a point-of-care analysis of lactate prior to arrival in hospital might improve the detection rate still further [39].

\section{Discussion}

There is no clear evidence from the literature that, if possible, the treatment of sepsis should start in the prehospital setting. However, it appears that the time to the delivery of treatment is important for outcome and the earlier such treatment is started the better. In this aspect there are many similarities between sepsis and acute myocardial infarction. In the latter "time is saved myocardium" is known since many years.

One striking observation was the lack of reports from a prehospital perspective with regard to the patients', bystanders' and dispatchers' perspective. We need further knowledge in order to see improvements in these links in the prehospital chain of care. It is not easy to calculate room for improvement if we do not have sufficient knowledge about the situation at present.

The observation of a limited knowledge regarding sepsis among EMS staff suggests that there is room for improvement in the capability to recognise sepsis among patients, bystanders and dispatchers, as well as EMS staff. The way educational efforts to achieve these goals should be structured remains to be determined.
It is also time to try to assess whether structural changes in the early chain of care in sepsis should be made and evaluated.

\section{Should sepsis patients who use the EMS be directly transported to a sepsis treatment ward, bypassing the ED?}

Among patients with an ST-elevation myocardial infarction and stroke who are transported by the EMS, it has become a common procedure to bypass the ED and transport the patient directly to the cath lab and also in some hospitals to a stroke unit $[40,41]$.

In patients with sepsis, this has not yet been evaluated. The situation in sepsis might be different, as organisations have been introduced at the ED in many countries to take immediate care of these patients, thereby making direct transport to an intensive care less meaningful.

How should we optimise the communication between the EMS staff and the hospital regarding sepsis patients?

In the future, it is most likely that the opportunity to detect sepsis prior to arrival in hospital will improve. In order to improve the communication between the prehospital and the hospital team as in acute myocardial infarction and stroke $[40,41]$ a sepsis coordinator within the hospital ED might be required. In all probability, a "hot line" could be set up between the EMS staff and the sepsis co-ordinator and this would most probably increase the preparedness of the "hospital staff" responsible for the initial care of sepsis patients and thereby shorten the delay to the start of life-saving treatment.

\section{Is there an association between EMS detection of sepsis} and start of treatment?

In a previous report, it was found that, if there was a written impression of sepsis among EMS-transported patients at the scene, there was a shorter delay to the start of antibiotics and the start of EGDT [33].

\section{Is there an association between the use of the EMS and treatment and outcome in sepsis?}

In two previous surveys, it was found that, in prospective observational studies among patients with severe sepsis, those who used the EMS had a shorter delay to the start of antibiotics and to the start of EGDT compared with those patients who did not use the EMS $[32,42]$. However, no previous study has confirmed an association between the use of EMS and outcome in sepsis.

\section{Biochemical detection of sepsis}

Biochemical detection of various diseases including acute myocardial infarction in the prehospital setting is 
uncommon. In sepsis only lactate has been suggested as such a marker at present.

\section{How easy is it to tell when a common cold or flu turns into pneumonia and ultimately sepsis?}

There is no distinct answer to this question. In the prehospital setting one might answer: "Follow your MEWS", Modified Early Warning Signs. When the respiratory rate rises to nearly $30 / \mathrm{min}$ or the oxygen saturation deteriorates below $90 \%$ or systolic blood pressure decreases below $90 \mathrm{mmHg}$ or the level of consciousness is decreasing, then one must suspect a bacterial complication.

\section{Conclusion}

Severe sepsis is a life-threatening condition. Previous studies suggest that, with every hour of delay until the start of antibiotics, the prognosis deteriorates. About half of patients use the EMS and less than half of sepsis cases are detected by EMS staff. We need to know more about the present situation with regard to the different links in the prehospital chain of care in sepsis.

\section{Competing interests}

The authors declare that they have no competing interests.

\section{Authors' contributions}

$\mathrm{JH}$ is responsible for the design of the manuscript, the literature search and the writing of the manuscript. $A B$ has contributed constructive comments. BW has contributed constructive comments. CA has contributed constructive comments. $\mathrm{AB}$ has contributed constructive comments and references. $\mathrm{MH}$ has contributed constructive comments and references. AJ has contributed constructive comments. LL has contributed constructive comments. BS contributed constructive comments. LL has contributed valuable background information which was of importance for the design and content of the manuscript. All authors read and approved the final manuscript.

\section{Acknowledgement}

This study was supported by grants from the Laerdal Foundation for Acute Medicine in Norway and by The Health \& Medical Care Committee of the Regional Executive Board, Region Västra Götaland.

Many thanks to the librarians at the Medicine Library at Sahlgrenska University Hospital, Yomine Holmberg and Ann Liljegren, for their skilful support.

\section{Author details}

${ }^{1}$ School of Health Sciences, Research Centre PreHospen, University of Borås, The Prehospital Research Centre of Western Sweden, SE 501 90, Borås, Sweden. ${ }^{2}$ Department of Infectious Diseases, Skövde Central Hospital, Skövde, Sweden. ${ }^{3}$ Sahlgrenska University Hospital, SE 413 45, Göteborg, Sweden.

Received: 3 January 2012 Accepted: 25 April 2012 Published: 27 June 2012

\section{References}

1. Hollenberg J, Herlitz J, Lindqvist J, Riva G, Bohm K, Rosenqvist M, Svensson L: Improved survival after out-of-hospital cardiac arrest is associated with an increase in proportion of emergency crew - witnessed cases and bystander cardiopulmonary resuscitation. Circulation 2008, 118:389-396.

2. Angus DC, Linde-Zwirble WT, Lidicer J, et al: Epidemiology of severe sepsis in the United States: Analysis of incidence, outcome, and associated costs of care. Crit Care Med 2001, 29:303-1310.
3. Rivers E, Nguyen B, Havstad S, Ressler J, Muzzin A, Knoblich B, Peterson E, Tomlanovich M: for the Early Goal-Directed Therapy Collaborative Group: Early goal-directed therapy in the treatment of severe sepsis and septic shock. New Engl J Med 2001, 345:1368-1377.

4. Nguyen HB, Corbett SW, Steele R, Banta J, Clark RT, Hayes SR, Edwards J, Cho TW, Wittlake WA: Implementation of a bundle of quality indicators for the early management of severe sepsis and septic shock is associated with decreased mortality. Crit Care Med 2007, 35:1105-1112.

5. MacRedmond R, Hollohan K, Stenstrom R, Nebre R, Jaswal D, Dodek P. Introduction of a comprehensive management protocol for severe sepsis is associated with sustained improvements in timeliness of care and survival. Qual Saf Health Care 2010, 19:e46.

6. Siddiqui S, Salahuddin N, Raza A, Razzak J: How early do antibiotics have to be to impact mortality in severe sepsis? A prospective observational study from an emergency department. J Ayub Med Coll Abbottabad 2009, 21:106-110.

7. Gaieski DF, Mikkelsen ME, Band RA, Pines JM, Massone R, Furia FF, Shofer FS, Goyal M: Impact of time to antibiotics on survival in patients with severe sepsis or septic shock in whom early goal-directed therapy was initiated in the emergency department. Crit Care Med 2010, 38:1045-1053.

8. Levy MM, Fink MP, Marshall JC, Abraham E, Angus D, Cook D, Cohen J, Opal SM, Vincent J-L, Ramsay G: 2001 SCCM/ESICM/ACCP/ATS/SIS International sepsis definitions conference. Crit Care Med 2003, 31:1250-1256.

9. Marshall JC, Cook DJ, Christou NV, et al: Multiple organ dysfunction score: A reliable descriptor of a complex clinical outcome. Crit Care Med 1995, 23:1638-1652.

10. Ferreira FL, Bota DP, Bross A, et al: Serial evaluation of the SOFA score to predict outcome in critically ill patients. JAMA 2002, 286:1754-1758.

11. Bone RC, Balk RA, Cerra FB, Dellinger RP, Fein AM, Knaus WA, Schein RM, Sibbald WJ: Definitions for sepsis and organ failure and guidelines fort he use of innovative therapies in sepsis. The ACCP/SCCM Consensus Conference Committee. American College of Chest Physicians/Society of Critical Care medicine. Chest 1992, 101:1644-1655.

12. Nguyen HB, Corbett SW, Menes K, Cho T, Daugharthy J, Klein W, Wittlake WA: Early goal-directed therapy, corticosteroid, and recombinant human activated protein $C$ for the treatment of severe sepsis and septic shock in the emergency department. Acad Emerg Med 2006, 13:109-113.

13. Gaieski D, Goyal M: The implementation of new therapies for severe sepsis: Some questions raised by "Early goal-directed therapy, corticosteroid, and recombinant human activated protein $\mathrm{C}$ for the treatment of severe sepsis and septic shock in the emergency department". Acad Emerg Med 2006, 13:997-999.

14. Melandez $E$, Bachur R: Advances in the emergency management of pediatric sepsis. Curr Opin Pediatr 2006, 18:245-253.

15. Trzeciak S, Dellinger $P$, Abate NL, Cowan RM, Stauss M, Kilgannon H, Zanotti S, Parrillo JE: Translating research to clinical practice. A 1-year experience with implementing early goal-directed therapy for septic shock in the emergency department. Chest 2006, 129:225-232.

16. Jones AE, Focht A, Horton JM, Kline JA: Prospective external validation of the clinical effectiveness of an emergency department-based early goaldirected therapy protocol for severe sepsis and septic shock. Chest 2007, 132:425-432.

17. Sivayoham N: Management of severe sepsis and septic shock in the emergency department: a survey of current practice in emergency departments in England. Emerg Med J 2007, 24:422.

18. Inwald DP, Tasker RC, Peters MJ, Nadel S: on behalf of the Paediatric Intensive Care Society Study Group: Emergency management of children with severe sepsis in the United Kingdom: the results of the Paediatric Intensive Care Society sepsis audit. Arch Dis Child 2009, 94:348-353.

19. Puskarich MA, Marchick MR, Kline JA, Steuerwald MT, Jones AE: One year mortality of patients treated with an emergency department based early goal directed therapy protocol for severe sepsis and septic shock: a before and after study. Crit Care 2009, 13(5):R167.

20. Vanzant AM, Schmelzer M: Detecting and treating sepsis in the emergency department. J Emerg Nurs 2011, 37:47-54.

21. Yan $H$, Song L, Yang J, Sun Y, Hu D: The association between preinfarction angina and care-seeking behaviors and its effects on early reperfusion rates for acute myocardial infarction. Inter J Cardiol 2009, 135:86-92. 
22. Frankel M, Hinchey J, Schwamm LH, Wall H, Rose KM, George MG, McGruder HF, Liban A, Croft JB: Prehospital and Hospital Delays After Stroke Onset United States, 2005-2006. MMWR. Morbidity and Mortality Weekly Report 2007, 56:474-478.

23. Sörensen HT, Nielsen GL, Schönheyder HC, Steffensen FH, Hansen I, Sabroe S, Dahlerup JF, Hamburger H, Olsen J: Outcome of pre-hospital antibiotic treatment of meningococcal disease. J Clin Epidemiol 1998, 51:717-721.

24. Nörgård B, Sörensen HT, Jensen ES, Faber T, Schönheyder HC, Nielsen GL: Pre-hospital parenteral antibiotic treatment of meningococcal disease and case fatality: a Danish population-based cohort study. J of Infection 2002, 45:144-151.

25. Harnden A, Ninis N, Thompson M, Perera R, Levin M, Mant D, MayonWhite R: Parenteral penicillin for children with meningococcal disease before hospital admission: case-control study. BMJ 2006 332:1295-1298.

26. Cooke ME: Special Theme - meningococcal disease. Prehospital Administration of Benzyl Penicillin by Paramedics in the UK. J Emerg Primary Health Care (JEPHC) 2005, 3(Issue):1-2.

27. Barquet N, Domingo P, Cayla JA, González J, Rodrigo C, Fernández-Viladrich P, Moraga-Llop FA, Marco F, Vázquez J, Sáez-Nieto JA, Casal J, Canela J, Foz $M$ : Prognostic factors in meningococcal disease. Development of a bedside predictive model and scoring system. Barcelona Meningococcal Disease Surveillance Group. JAMA 1997, 278:491-496.

28. Barquet N, Domingo P, Cayla JA, González J, Rodrigo C, Fernández-Viladrich P, Moraga-Llop FA, Marco F, Vázquez J, Sáez-Nieto JA, Casal J, Canela J, Foz M: Meningococcal disease in a large urban population (Barcelona, 19871992): predictors of dismal prognosis. Barcelona Meningococcal Disease Surveillance Group. Arch Intern Med 1999, 159:2329-2340.

29. Nonell F, Sobrino J, Torres M: On meningococcal disease, its prognosis, and undernotification of the Public Health Service. Arch Intern Med 2000, 160:2219-2220.

30. Radetsky M: Oral antibiotics and outcome in meningococcemia. Arch Intern Med 2000, 160:2220-2221.

31. Henriksson C, Lindahl B, Larsson M: Patients' and relatives' thoughts and actions during and after symptom presentation for an acute myocardial infarction. Eur J Cardiovasc Nurs 2007, 6:280-286.

32. Studnek JR, Artho MR, Garner CL, Jones AE: The impact of emergency medical services on the ED care of severe sepsis. Am J Emerg Med 2012, 30:51-56.

33. Wang HE, Weaver MD, Shapiro NI, Yealy DM: Opportunities for emergency medical services care of sepsis. Resuscitation 2010, 81:193-197.

34. Seymour CW, Band RA, Cooke CR, Mikkelsen ME, Hylton J, Rea TD, Goss CH, Gaieski DF: Out-of-hospital characteristics and care of patients with severe sepsis: A cohort study. J Crit Care 2010, 25:553-562.

35. Wilcox SR, Hanudel P, Cadin E, Hou P, Baez AA, Brigham and Women's Hospital/Harvard Medical School, Boston MA: Harvard Medical School, Boston, MA; Brigham and Women's Hospital, Boston, MA: Out-ofHospital Physiolog Predictors of Sepsis Outcomes. Annals of Emerg Med 2007, 50(3):S79. Research Forum, Abstracts.

36. Seymour CW, Cooke CR, Mikkelsen ME, Hylton J, Rea TD, Goss CH, Gaieski DF, Band RA: Out-of-hospital fluid in severe sepsis: Effect on early resuscitation in the emergency department. Prehosp Emerg Care 2010, 14:145-152.

37. Wheeler AP, Bernard GR: Treating patients with severe sepsis. New Engl J Med 1999, 340:207-214.

38. Báez AA, Hanudel P, Wilcox SR, Perez MT, Giraldez EM: Prehospital sepsis project: Knowledge and attitudes of United States advanced out-ofhospital care providers. Prehosp Disaster Med 2010, 25:41-43.

39. Robson W, Nutbeam T, Daniels R: Sepsis: a need for prehospital intervention?. Emerg Med J 2009, 26:535-538.

40. Bång A, Grip L, Herlitz J, Kihlgren S, Karlsson T, Caidahl K, Hartford M: Lower mortality after prehospital recognition and treatment followed by fast tracking to coronary care compared with admittance via emergency department in patients with ST-elevation myocardial infarction. Inter J Cardio/ 2008, 129:325-332.

41. De Luca A, Toni D, Lauria L, Sacchetti ML, Rossi PG, Ferri M, Puca E, Prencipe M, Guasticchi G: An emergency clinical pathway for stroke patients - results of a cluster randomised trial. BMC Heal Serv Res 2009, 9:14.
42. Band RA, Gaieski DF, Hylton JH, Shofer FS, Goyal M, Meisel ZF: Arriving by emergency medical services improves time to treatment endpoints for patients with severe sepsis or septic shock. Acad Emerg Med 2011, 18:934-940.

doi:10.1186/1757-7241-20-42

Cite this article as: Herlitz et al:: Suspicion and treatment of severe sepsis. An overview of the prehospital chain of care. Scandinavian Journal of Trauma, Resuscitation and Emergency Medicine 2012 20:42.

\section{Submit your next manuscript to BioMed Central and take full advantage of:}

- Convenient online submission

- Thorough peer review

- No space constraints or color figure charges

- Immediate publication on acceptance

- Inclusion in PubMed, CAS, Scopus and Google Scholar

- Research which is freely available for redistribution 